\title{
PENGARUH PENDAPATAN DAN JUMLAH ANGGOTA RUMAH TANGGA TERHADAP KONSUMSI DAGING BABI DI KELURAHAN RURUKAN 1 KECAMATAN TOMOHON TIMUR KOTA TOMOHON
}

\author{
Rifaldy Marsel Wowiling, J. Pandey, V.L.H Rembang, E.K.M. Endoh* \\ Fakultas Peternakan Universitas Sam Ratulangi Manado, 95115
}

\begin{abstract}
ABSTRAK
Penelitan bertujuan untuk mengetahui rataan konsumsi daging babi dan pengaruh pendapatan dan jumlah anggota rumah tangga terhadap konsumsi daging babi. Penelitian dilakukan di Kelurahan Rurukan 1 Kecamatan Tomohon Timur Kota Tomohon dari bulan November sampai Desember 2019, dengan menggunakan metode survey. Riset menemukan bahwa rataan jumlah konsumsi daging per bulan per rumah tangga sudah lebih besar dari $2 \mathrm{~kg}$. selanjutnya, hasil dan pembahasan menunjukkan pendapatan dan jumlah anggota keluarga secara amat nyata mempengaruhi konsumsi daging babi pada taraf kesalahan 1 persen $(\mathrm{P}<0,01)$. Pendapatan rumah tangga berpengaruh amat nyata terhadap konsumsi daging babi pada taraf kesalahan 1 persen $(\mathrm{P}<0,01)$. Jumlah anggota rumah mempengaruhi konsumsi daging babi secara nyata pada taraf kesalahan 5 persen $(\mathrm{P}<0,05)$. Berdasarkan tujuan penelitian, disimpulkan bahwa rataan konsumsi daging babi per rumah tangga per bulan mencapai $2,2 \mathrm{~kg}$ dan pendapatan dan jumlah anggota rumah tangga berpengaruh secara amat nyata pada taraf kesalahan 1 persen $(\mathrm{P}<0,01)$.
\end{abstract}

Kata Kunci: Pendapatan, Jumlah Anggota

Keluarga dan Konsumsi

Daging Babi

Korespondensi (corresponding author): E-mail: eusebiusendoh@unsrat.ac.id

ABSTRACT

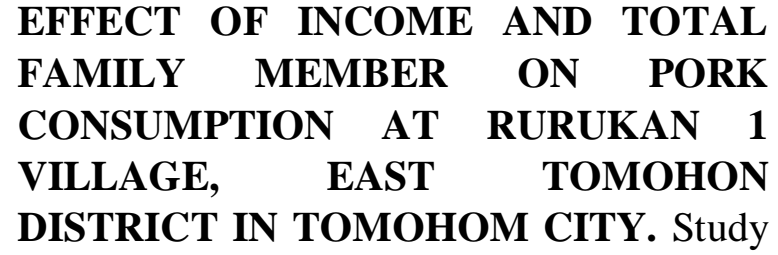
was conducted to evaluate effect of income and total family member on average pork consumption at Rurukan 1 village, East Tomohon district in Tomohom city. Study was done on November to December 2019, using survey method. Study showed that average pork consumption per month of the family was two $\mathrm{kg}$. Income of family member affected significantly $(\mathrm{P}<0.01)$ of pork consumption. In addition, total family member affected significantly $(\mathrm{P}<0.05)$ of pork consumption. Therefore, it can be concluded that average pork consumption per family per month reached $2.2 \mathrm{~kg}$, significantly affected by income and total family member at Rurukan 1 village, East Tomohon district in Tomohom city.

Key Word: Income, total family member, family pork consumption.

\section{PENDAHULUAN}

Konsumsi merupakan pembelanjaan yang dilakukan oleh rumah tangga atas barang-barang akhir dan jasa-jasa dengan tujuan untuk memenuhi kebutuhan dari 
orang-orang yang melakukan pembelanjaan tersebut, capaian konsumsi protein untuk penduduk Indonesia jika dibandingkan dengan angka rata-rata kecukupan protein yang diisyaratkan yaitu 46,20 gram/kapita/hari, maka angka konsumsi protein 55,23 gram/kapita/hari tahun 2009 telah melebihi yang dianjurkan, artinya secara kuantitas sudah mencukupi. Masalahnya capaian konsumsi protein hewani belum mencukupi, norma gizi protein hewani sebesar 15 gram/kapita/hari. Standar kebutuhan protein hewani ini diharapkan 9 gram/kapita/hari bersumber dari komoditi peternakan yang setara dengan daging $10,3 \mathrm{~kg} / \mathrm{kapita} / \mathrm{tahun}$, telur 6,5 kg/kapita/tahun, dan susu 7,2 $\mathrm{kg} / \mathrm{kapita} /$ tahun juga masih belum tercapai. Masyarakat Sulawesi Utara khususnya sampai saat ini standar konsumsi protein hewani asal ternak belum tercukupi yaitu baru sebesar 4,84 gram/kapita/hari sedangkan untuk konsumsi protein asal ikan sebesar 14,41 gram/kapita/hari (Badoa,et al 2016).

Peningkatan konsumsi daging tergantung pada pendapatan masyarakat disuatu wilayah. Semakin tinggi pendapatan dan jumlah anggota rumah tangga maka kecenderungan untuk mengkonsumsi daging semakin tinggi juga (Osak, et al. 2014,
Prihartini, 2006, Rahayu, et al. 2018,Weol, et al. 2014). Masalahnya belum diketahui pengaruh pendapatan dan jumlah anggota rumah tangga terhadap konsumsi daging babi di daerah Tomohon. Bertitik tolak dari data dan fakta tersebut, maka penelitian ini berusaha mengetahui faktor faktor yang berpengaruh padakonsumsi daging babi oleh masyarakat di Kelurahan Rurukan Satu .

\section{METODE PENELITIAN}

Penelitian ini telah dilaksanakan di Kelurahan Rurukan 1 Kecamatan Tomohon Timur Kota Tomohon mulai dari bulan November sampai Desember 2019. Metode yang digunakan adalah metode survey. Menurut Singarimbun dan Effendy (2009), metode survey adalah penelitian yang mengambil sampel dari satu populasi dan menggunakan kuesioner sebagai alat pengumpul data yang pokok. Data yang diambil terdiri dari data primer dan sekunder. Data Primer yaitu data yang berasal dari sumber asli atau responden yang diperoleh melalui wawancara dengan menggunakan daftar kuesioner. Data primer dalam penelitian ini seperti informasi pendapatan, jumlah anggota rumah tangga dan informasi tingkat konsumsi daging babi per rumah tangga (Kg/bulan). Data sekunder yaitu data yang diperoleh melalui dinas pertanian dan peternakan kota Tomohon, 
data dari BPS Tomohon dan kantor Kelurahan Rurukan Satu. Data sekunder ini seperti data profil kelurahan, data kependudukan dan agama.

Penentuan lokasi ini dilakukan secara purposive sampling karena memiliki penduduk yang keseluruhannya beragama Kristen dan Katolik (mengkonsumsi daging babi).

Menurut Arikunto (2013), sampel adalah sebagian atau wakil dari populasi yang akan diteliti. Bila populasi besar dan peneliti tidak memungkinkan mempelajari semua yang ada pada populasi karena keterbatasan dana, tenaga dan waktu, maka peneliti dapat menggunakan sampel dari data yang diambil dari populasi itu. Jika subjek dalam penelitian kurang dari 100 orang sebaiknya diambil semuanya, jika subjeknya besar atau lebih dari 100 orang maka sampel penelitian dapat diambil berkisar $10 \%-15 \%$ atau $20 \%-25 \%$ dari jumlah total populasi tersebut.

Penelitian ini akan mengambil sampel sebanyak $10 \%$ dari jumlah populasi. Sehingga diperoleh sampel sebanyak 34 rumah tangga.

Definisi Operasional variabel penelitian :

1. Pendapatan rumah tangga adalah nilai rupiah yang diperoleh seluruh anggota rumah tangga dari mata pencahariannya atau sumber-sumber lain, dinyatakan dalam satuan rupiah per bulan.

2. Jumlah anggota rumah tangga adalah jumlah tanggungan yang ada dalam satu rumah, dinilai dalam satuan orang.

3. Konsumsi daging babi adalah jumlah daging babi yang dibeli oleh anggota rumah tangga, dinyatakan dalam satuan kilogram per bulan. Berdasarkan variabel dan pengukuranya, maka dalam penelitian ini dilakukan beberapa asumsi yang bermanfaat untuk membatasi satuan pengukuran variabel-variabelnya. Asumsi- asumsi itu sebagai berikut :

1. Jumlah daging babi yang akan dihitung dalam penelitian ini yaitu jumlah daging yang dibeli oleh anggota rumah tangga responden

2. Jumlah daging babi yang dikonsumsi diluar rumah tangga responden tidak akan dihitung dalam penelitian ini.

3. Responden yang diambil dalam penelitian ini adalah rumah tangga yang mengkonsumsi daging babi.

4. Daging babi yang dimaksud dalam penelitian ini adalah semua bagian karkas ternak babi. 
Berdasarkan tujuan penelitian untuk mengetahui besarnya konsumsi daging babi per rumah tangga maka data akan dirasionalisasi, ditabulasi dan dianalisis secara deskriptif berupa persentase, total, dan rataan data. Model analisis secara deskriptif dilakukan terhadap data konsumsi daging, pendapatan rumah tangga dan jumlah anggota rumah tangga diinterpretasikan dalam bentuk proporsi atau presentase. (2) Untuk mengetahui pengaruh pendapatan rumah tangga, jumlah anggota rumah tangga dan pengeluaran daging babi terhadap konsumsi daging babi akan dianalisis dengan menggunakan analisis regresi linear berganda. Analisis regresi berganda merupakan suatu metode statistik umum yang digunakan untuk menganalisis pengaruh antara sebuah variabel terikat dengan variabel bebas (Sulaiman, 2004) dengan rumus sebagai berikut :

$\mathrm{C}=\mathrm{b}_{0}+\mathrm{b}_{1} \mathrm{X}_{1}+\mathrm{b}_{2} \mathrm{X}_{2}+\mathrm{e}$

Keterangan :

$\mathrm{C}=$ Konsumsi daging babi oleh rumah tangga responden $(\mathrm{Kg})$

$\mathrm{X}_{1}=$ Pendapatan rumah tangga responden (Rp/Tahun)

$\mathrm{X}_{2}=$ Jumlah anggota rumah tangga (Orang)

e $\quad=$ Faktor Error $\mathrm{b}_{0} \quad=$ Koefisien arah (konstanta)

$b_{1} b_{2}=$ Koefisien regresi

(Ghozali, 2013), Pengujian hipotesis menggunakan uji Fhitung dan Thitung. Pengujian beda nyata menunjukkan kesesuaian hipotesis dengan jumlah variable yang terkait.

\section{HASIL DAN PEMBAHASAN}

\section{Keadaan Umum Lokasi Penelitian}

Kelurahan Rurukan Satu adalah salah satu kelurahan yang berada di Kecamatan Tomohon Timur kota Tomohon. Luas wilayah kelurahan ini adalah 155,8 $\mathrm{Ha} / 1.558 .000 \mathrm{~m}^{2}$, ketinggian wilayah 1062 $\mathrm{m}$ diatas permukaan laut dengan jumlah kepala keluarga 344 dan jumlah penduduk secara keseluruhan 1256. Sebelah timur kelurahan Rurukan Satu berbatasan dengan Kelurahan Wewelen dan sebelah barat, utara dan selatan berbatasan dengan wilayah Kelurahan Rurukan.

\section{Karakteristik Responden}

Hasil penelitian terhadap 34 responden di Kelurahan Rurukan Satu Kecamatan Tomohon Timur, menunjukan bahwa umur responden yang membeli dan mengkonsumsi daging babi antara 25 tahun sampai 64 tahun. Menurut Badan Pusat Statistik (BPS) usia 25-65 tahun digolongkan dalam usia kerja produktif. 
Keadaan ini mengindikasikan bahwa responden masih memiliki kemampuan mengalokasikan tenaga kerjanya untuk usaha produktif.

Perilaku konsumsi ditentukan oleh tingkat pengetahuan ekonomi yang dimiliki (Idrianawati, 2015). Dari hasil Penelitian jumlah responden yang tamat SMA merupakan presentase terbesar yaitu 35,29 $\%$ yang berarti tingkat pendidikan responden di Kelurahan ini cukup tinggi.

Pekerjaan merupakan sumber pendapatan utama dan tetap bagi responden (Syahriadi, 2011). Dari hasil penelitian menunjukan bahwa jenis pekerjaan setiap responden berbeda-beda yakni pegawai swasta, PNS, pedagang, tukang ojek dan petani yang menjadi jenis pekerjaan responden terbanyak dengan presentase $50,00 \%$.

Tinggi rendahnya tingkat pendapatan konsumen mempengaruhi daya beli terhadap barang yang dibutuhkan (Rachman, 2001).
Hasil dari penelitian menunjukan pendapatan responden bervariasi yaitu dari Rp.3.000.000 /bulan sampai Rp.12.000.000 /bulan. Jumlah pendapatan responden dapat dilihat pada Tabel 1.

Berdasarkan data Tabel 1 menunjukan bahwa sebagian besar rumah tangga responden memiliki pendapatan antara Rp.3.000.000 - Rp.6.000.000 per bulan dengan jumlah responden sebanyak 27 $(79,41 \%)$, sedangkan jumlah responden paling sedikit adalah pendapatan Rp.9.100.000 - Rp. 12.000.000 yaitu 3 rumah tangga $(8,82 \%)$. Jumlah pendapatan rumah tangga responden secara keseluruhan adalah Rp 178.000.000 dengan rata-rata pendapatan rumah tangga responden dalam penelitan sebesar Rp 5.235.294 per rumah tangga per bulan dibandingkan dengan hasil penelitian sebelumnya rata-rata pendapatan rumah tangga responden perbulan sebesar Rp. 2.554.000 masih lebih rendah (Keintjem 2015). Tabel 1. Jumlah Responden Berdasarkan Tingkat Pendapatan Rumah Tangga

\begin{tabular}{lccc}
\hline No & $\begin{array}{c}\text { Pendapatan } \\
(\mathrm{Rp})\end{array}$ & $\begin{array}{c}\text { Jumlah Responden } \\
(\text { Orang })\end{array}$ & $\begin{array}{c}\text { Presentase } \\
(\%)\end{array}$ \\
\hline 1 & $3.000 .000-6.000 .000$ & 27 & 79,41 \\
2 & $6.100 .000-9.000 .000$ & 4 & 11,77 \\
3 & $9.100 .000-12.000 .000$ & 3 & 8,82 \\
\hline Jumlah & & 34 & 100,00 \\
\hline
\end{tabular}


Tabel 2. Jumlah Anggota keluarga Responden Ditempat Penelitian

\begin{tabular}{lccc}
\hline No & Jumlah anggota keluarga & $\begin{array}{c}\text { Jumlah responden } \\
\text { (Orang) }\end{array}$ & $\begin{array}{c}\text { Presentase } \\
(\%)\end{array}$ \\
\hline 1 & 2 & 5 & 14,70 \\
2 & 3 & 14 & 41,18 \\
3 & 4 & 11 & 32,35 \\
4 & 5 & 4 & 11,77 \\
\hline Jumlah & & 34 & 100,00 \\
\hline
\end{tabular}

Prihartini (2006) menjelaskan dalam penelitiannya bahwa, jumlah anggota keluarga merupakan salah satu faktor yang mempengaruhi pola konsumsi pada rumah tangga. Pada Tabel 2, jumlah anggota keluarga responden dalam penelitian ini bervariasi dari $2-5$ anggota keluarga. Rumah tangga responden dengan 3 jumlah anggota keluarga menjadi yang terbanyak dengan jumlah responden sebanyak 14 responden $(41,18 \%)$ sedangkan responden dengan 5 anggota keluarga adalah yang terendah yaitu 4 responden $(11,77 \%)$. RataTabel 3. Jumlah Konsumsi Daging Babi Rumah Tangga Responden

\begin{tabular}{lccc}
\hline No & $\begin{array}{c}\text { Konsumsi daging babi } \\
(\mathrm{kg})\end{array}$ & $\begin{array}{c}\text { Jumlah Rumah Tangga } \\
(\text { Orang) }\end{array}$ & $\begin{array}{c}\text { Presentase } \\
(\%)\end{array}$ \\
\hline 1 & 1 & 13 & 38,23 \\
2 & 2 & 7 & 20,59 \\
3 & 3 & 9 & 26,47 \\
4 & 4 & 5 & 14,71 \\
\hline Jumlah & & 34 & 100,00 \\
\hline
\end{tabular}


Berdasarkan hasil penelitian daging babi dinyatakan dalam persamaan menunjukkan bahwa hasil penelitian ini berikut:

sejalan dengan penelitian sebelumnya bahwa $\mathrm{C}=-0,62+0,00000037 \mathrm{X}_{1}+0,43 \mathrm{X}_{2}$

konsumsi rata rata daging babi sebesar 1,25 $\mathrm{kg} / \mathrm{bulan}$ (Weol et al., 2014)

Se $\quad 0,46 \quad 0,0000001 \quad 0,18$

Hasil estimasi pengaruh pendapatan, Keterangan :

$$
\begin{aligned}
& \mathrm{C}=\text { konsumsi daging babi } \\
& \mathrm{X}_{1}=\text { pendapatan rumah tangga } \\
& \mathrm{X}_{2}=\text { jumlah anggota rumah tangga } \\
& \mathrm{Se}=\text { standar error }
\end{aligned}
$$

Variabel-variabel bebas yang mempengaruhi konsumsi daging babi adalah pendapatan (X1) dan jumlah anggota rumah tangga (X2) dengan menggunakan aplikasi program Excel. Model analisis regresi

Tabel 4. Estimasi Pengaruh Pendapatan dan Jumlah Anggota Rumah Tangga Terhadap Konsumsi Daging Babi

\begin{tabular}{lccc}
\hline \multicolumn{1}{c}{ Variabel } & Koefisien Parameter & Nilai Thit & Signifikansi \\
\hline Intersep & $-0,6213$ & $-1,34462$ & 0,188826 \\
Pendapatan(X1) & 0,000000375 & 3,672797 & $0,00093^{* * *}$ \\
JART (X2) & 0,430025 & 2,321499 & $0,027238^{* *}$ \\
\hline
\end{tabular}

***Fhit pada taraf kesalahan 1 persen $(\mathrm{P}<0.01)$

Adjusted R Square : 0,6484,

Multiple R : $\quad 0,8248$

Standard Error : $\quad 0,6603$

*** Signifikan pada $\alpha=0,01 ; \mathrm{P}<0,01$

** Signifikan pada $\alpha=0,05 ; \mathrm{P}<0,05$ 
Nilai koefisien regresi variabel pendapatan rumah tangga sebesar 0,00000037 dan signifikan pada taraf kesalahan 1\% dimana nilai koefisien regresi positif yang berarti pendapatan berpengaruh amat nyata pada konsumsi daging babi $(\mathrm{P}<0,01)$. Hal ini menunjukkan semakin besar pendapatan rumah tangga, maka semakin besar konsumsi daging babi dengan anggapan ceteris paribus. Hasil penelitian ini didukung Purwoko et al (2004), Rahayu et al (2018), Zulkarnain et al (2015), Weol et al (2014), dan Osak et al (2014).

Hasil analisis regresi pengaruh jumlah anggota rumah tangga terhadap konsumsi daging babi, memperoleh nilai koefisien sebesar 0,43 dan signifikan pada taraf kesalahan $5 \%$. Nilai positif ini bermakna bahwa semakin besar jumlah anggota rumah tangga, maka semakin besar jumlah konsumsi daging babi dengan anggapan ceteris paribus. Hasil penelitian ini didukung Kumaat et al (2019), Purwoko et al (2004), Rahayu et al (2018), Zulkarnain et al (2015).

Hasil pengujian secara simultan dengan menggunakan F-tes, menghasilkan nilai Fhit yang signifikan pada taraf kesalahan 1\%. Hal ini berarti pendapatan dan jumlah anggota rumah tangga secara bersama sama berpengaruh sangat signifikan
$(\mathrm{P}<0,01)$ terhadap konsumsi daging babi. Nilai Adjusted R Square $=0,6484$, ini berarti, perubahan konsumsi daging babi ditentukan oleh perubahan pendapatan dan jumlah anggota rumah tangga sebesar 64,84 persen, sementara 35,16 persen ditentukan faktor-faktor lain yang tidak dimasukan dalam model analisis dengan anggapan ceteris paribus.

Keeratan hubungan peubah bebas dengan peubah tidak bebas bernilai positif yakni 0,8248 , yang artinya setiap perubahan peubah bebas yakni pendapatan dan jumlah anggota rumah tangga secara positif diikuti perubahan konsumsi daging babi.

\section{KESIMPULAN}

Secara simultan maupun parsial pendapatan dan jumlah anggota rumah tangga mempengaruhi sangat nyata terhadap konsumsi daging babi oleh masyarakat di Kelurahan Rurukan Satu Kota Tomohon

\section{DAFTAR PUSTAKA}

Arikunto, S. 2013. Prosedur Penelitian, Suatu Pendekatan Praktik. Rineka Cipta.. Jakarta

Badoa, V.I., A.H.S. Salendu, F.H. Elly dan P.O.V. Waleleng. 2016. Pengaruh pendapatan terhadap konsumsi daging dan telur di Kecamatan Siau Barat Kabupaten Kepulauan Siau 
Tagulandang Biaro. Journal Zootek $36(1): 61-68$.

Ghozali, I. 2013. Aplikasi Analisis Multivariate Dengan Program SPSS 21 Update Analisis Regresi.: Penerbit Universitas Diponegoro. Semarang

Idrianawati, E. 2015. Pengaruh tingkat pendapatan dan pengetahuan ekonomi terhadap tingkat konsumsi mahasiswa. Journal Ekonomi Pendidikan dan Kewirausahaan 3 (1) : $104-108$.

Keintjem, R., F.S. Oley, G.D. Lenzun dan J. Pandey. 2016 . Pengaruh pendapatan terhadap konsumsi daging babi di Kecamatan Wanea Kelurahan Ranotana Weru. Journal Zootek 36 (1) : $139-146$.

Kumaat, B.K.M., F.H. Elly, E. Wantasen dan L.S Kalangi. 2019. Analisis konsumsi daging babi oleh masyarakat pesisir danau Tondano. Journal Zootek 39 (2): 249-256.

Osak, R.A.F., V.V.J. Panelewen, J. Pandey dan I.D.R. Lumenta. 2014 . Pengaruh pendapatan rumah tangga terhadap konsumsi daging (sapi, babi dan ayam) di Desa Sea 1 Kecamatan Pineleng. Journal Zootek 34 (2) 10 17.

Purwoko, A., M.M. Romdhon dan Subagyo. 2004. Analisis permintaan ayam potong oleh pedagang pengecer dan tingkat konsumsi rumah tangga terhadap daging ayam potong di Kota Bengkulu. Journal Agrisep 3 (1): 1-13.
Prihartini, D.A. 2006. Perbandingan total kemiskinan versi pemerintah indonesia dan bank dunia dengan peran strategis dari usaha mikro untuk pengentasan kemiskinan. Journal Fakultas Ekonomi Universitas Gunadarma Depok 1 (1) : 73 - 92 .

Rachman, H.P.S. 2001. Kajian pola konsumsi dan permintaan pangan masyarakat berpendapatan rendah di Jawa Tengah dan Nusa Tenggara Barat. Journal Agro Ekonomi 15 (2) : $36-5$

Rahayu, R.D. dan M. Long. 2018. Faktor faktor yang berpengaruh terhadap keputusan pemilihan daging ayam broiler sebagai konsumsi rumah tangga di surakarta. Journal Sains Peternakan 16 (1) : 11-18

Singarimbun, Masri dan S. Effendi. 2008. Metode penelitian survei, Jakarta: LP3ES.

Sulaiman, W. 2004. Analisis Regresi Menggunakan SPSS . Andi Offset. Yogyakarta.

Weol, E.F., B Rorimpandey, G.D. Lenzun dan E.K.M. Endoh. 2014. Analisis pengaruh pendapatan rumah tangga terhadap konsumsi daging dan telur di Kecamatan Suluun Tareran Kabupaten Minahasa Selatan. Jurnal Zootek 34 (1) : 37 - 40.

Zulkarnain dan Sofyan. 2015. Analisis konsumsi daging sapi pada tingkat rumah tangga di Provinsi Aceh. Journal Agrisep 4 (1) : 82 -89 
